\title{
The Search for Identity in Selected Poems by Martin Carter and Mahmoud Darwish.
}

\author{
By \\ Mai Mostafa Reda Mohamed
}

Minia University

\begin{abstract}
$\underline{\text { Abstract }}$
This paper tackles the theme of searching the lost identity in selected poems by Martin Carter and Mahmoud Darwish. It also demonstrates how both poets contribute in raising the awareness of their people in the anti-colonial struggle against colonialism. They uncover the colonizers' trials to destroy the self-image of the oppressed by emphasizing the individual and the collective identity of their people. The paper ends with a conclusion which demonstrates a comparison between both poets to clarify the points of similarity and difference between them dealing with such issue.
\end{abstract}

\section{Introduction.}

Gordon Rohlehr in his article, "Search in the Caribbean through Literature" claims:

...the idea of a quest for identity often leads to the belief that identity is something which can be defined in clear-cut terms or which one discovers near the side of a road somewhere and then keeps in cold storage to be brought out and displayed on the appropriate occasion. But identity is something which one continually expresses and which artists explore, some superficially, others, in depth. (187)

According to this view, identity has an intangible dimension as one couldn't give it a precise definition. It can be defined with a relation to many aspects such as personality, religion, culture, history or a whole nation. As the previous quotation suggests, identity is closely connected to expression. It is through expression that people's identity can be understood. Although identity can be expressed in a variety 
of forms but still the major medium of expression for anything is the language. So, many writers use their literary language as a reliable device to express their identity through their works. Resistance literature comes to be a fully suitable device to serve the writers' purposes of searching their identity.

\section{The search for identity in selected poems by Martin Carter}

For centuries, the identity of the Caribbean people was denied and distorted in the colonialist literature. The content of these literary works was predictable since European imperialism tended to wipe out the cultural identity of the colonized. The imperial powers imposed degraded self-images of the colonized as an effective means of affirming their hegemony. These images tended to justify the established social and political conditions made by the colonizers over the region. As slavery and colonization become the natural fate of the Caribbean. This strategy met an echo in literature accompanied by growing anti-colonial voices in the Caribbean islands. It gave rise to the preoccupation of the Caribbean writers with the question of the cultural identity of their oppressed people. Nicholas Laughlin in his article "What 'Caribbean' can mean” claims that "defining the Caribbean identity is problematic because the Caribbean includes many places such as Cuba, Florida, Venezuela, Belize and other locations that contain dozens of ethnic and racial groups and much mixing of cultures" (87).

On referring to the Caribbean identity, it is a must to surpass all the barriers made by the hands of colonization to reach a new awareness of the self. This can be achieved through a process of cultural knowledge that will help in restoring the lost identity. Unifying the Caribbean region around a collective identity and a common history will be a destructive blow to the colonialism. Central to my argument is that all influences of the past must be recognized for their significant role in the Caribbean experiences.

The need to form a cultural and national identity that is distinct from their colonizers, led many Caribbean intellectuals, to cling to the idea of a united Caribbean nation. A common historical legacy of slavery and colonialism is an integral part of 
their identity. Thus, the main thrust of Carter's writings about his past in general and his ancestors, in particular, is the need to articulate an awareness of his existence. Clem Seecharan in his essay "The Shape of The passion" illustrates that one can trace Carter's own quest for an authentic Guyaneseness, rooted in slavery. Giving an example of Carter's poem, "I Came from the Nigger Yard" which is talking about the redefining of the past, and its reclamation as an instrument of renewal; the reassertion of one's humanity as a prelude to the building of the new day. "It epitomizes the emotional turmoil in all of us when we open our eyes every day to confront the scorn and contempt of those who wield the sword over our lives" (31). Carter says:

I come from the nigger yard of yesterday leaping from the oppressors' hate and the scorn of myself; from the agony of the dark hut in the shadow and the hurt of things; from the long days of cruelty and the long nights of pain down to the wide streets of tomorrow, of the next day leaping I come, who cannot see will hear.

It was an aching floor on which I crept On my hands and my knees Searching for dust for the trace of a root or the mark of a leaf or the shape of a flower.

...I take again my nigger life, my scorn and fling it in the face of those who hate me It is me the nigger boy turning to manhood linking my fingers, welding my flesh to freedom.

... From the nigger yard of yesterday I come with my burden. To the world of tomorrow I turn with my strength.

(Poems of Resistance)

From the first lines, it can be noticed that the poem is narrated by a person who is one of the silenced and oppressed native. Carter declares that he belongs to the nigger slums which were exclusive places for the slaves who work in the sugar 
plantation in the Caribbean. In spite of the fact that Carter, in reality, doesn't belong to this class but with such declaration he proves his sense of belonging to his people. The word /yesterday/ is an indication to his past and the state of slavery. The motion in the word/ leap/ gives the reader a visual image of a person who is willing to escape his colonial fate. He decides to get rid of his oppressor's grip and to kill this sense of humiliation made by the colonizers. His pain has to be stopped, using the metaphor of / the dark hut in the shadow/ shows that the poet is fed up with being marginalized. He cannot stand anymore the long days of turmoil and suffering. Thus, he determines that he will put this slavery to an end, fight for his freedom and declare his existence to the whole world. In a dynamic image of him and crowds of black people thronging the wide streets with angry shouts, he promises that the entire world will realize their presence. Then, the narrator locates himself as a responsible man confined to the shadows of the nigger yard. He describes how he suffered in a world that refuses to acknowledge him. This stanza paints the dark visual images of the narrator's world, the /dark hut in the shadow, / the aching floor on which I crept, / the /nigger yard of yesterday/. Also, the verbs used /leap, crept, search/ emphasize the harsh conditions that the speaker suffers in a barren land. However, all this cruel reality doesn't stop him from moving towards his hope for /the wide streets of tomorrow/. One can conclude that the whole stanza is a metonymy for the miserable life lived by the writer. It expresses the physical and the psychological suffering caused by colonialism.

What is remarkable about the last stanza is that the elements of pride and hope are introduced. The child is now grown up and becomes a mature man. It is an image of a human being's dream conquering darkness and struggling against the world of sorrows. Although the giant shadow of colonialism is still there but the dream is more powerful. The pronoun /I/ is not used to reflect only the hopes of the poet but also to reflect all oppressed people's histories and lives. In the last two lines, the narrator points out that the past had the heavy burden of anguish and distress, but the future has to surrender to his strength. Carter affirms his identity and shows us his rage and refusal to those who took his land and tried to erase his existence. He is reclaiming his African side; no place here for the European side. His insistence on 
getting his redemption is unlimited. He is documenting the process in which the oppressed are coming to consciousness. Carter's words are especially valuable because of his ability to speak for those who are involved in the struggle as one of them. This poem shows the poet's attempt to record the voices of the subjugated people restoring their lost identity.

In order to understand the concept of the individual identity, we need first to stand on the factors that make it as a crisis. In Questions of Cultural Identity, Stuart Hall states that a distinctive type of structural change is fragmenting the cultural landscapes of class, gender, ethnicity, race, and nationality which gave us a firm location as social individuals. These changeable factors are also shifting our personal identities, weakening our sense of ourselves as integrated subjects. This loss of a stable "sense of self" is sometimes called the dislocation or de-centering of the subject which means displacing individuals both from their place in the social and cultural world and from themselves. This set of double displacements constitutes a "crisis of identity" for the individual. Identity only becomes an issue when it is in crisis, when something assumed to be fixed, coherent and stable is displaced by the experience of doubt and uncertainty (597-598).

Continuing the focus on the individual identity, Ralph R. Premdas in his article "Ethnicity and Identity in the Caribbean" argues that identity as belonging can be acquired through membership in various communities bound by one or more social attributes such as race, language, religion, culture, and region. In each case, the individual perceives subjectively and emphatically regardless of objective and empirical facts, that his or her relation to a linguistic, religious, or cultural community is a unique link that confers a special sense of personal value, importance and collective meaning (10).Thus, if the individual wants to preserve his identity, he has to stick to this uniqueness in his relation to the previous factors.

Discussing the individual identity, in "Proem", Carter invites the reader to rethink of the theme of identity and to try to reach to another sphere for the definition. Here, identity is not for a country or for a certain group of people but it is for each 
single person separately. He raises the question of how each one of us defines himself. Carter invites the reader to face the mere fact that a person has to accept himself the way he is. Carter writes:

\author{
Not, of the saying of you, are you \\ said .Baffled and like a root \\ stopped by a stone you turn back questioning \\ the tree you feed. But what the leaves hear \\ is not what the roots ask. Inexhaustibly, \\ being at one time what was to be said \\ and at another time what has been said \\ the saying of you remains the living of you \\ never to be said. But, enduring, \\ you change with the change that changes \\ and yet are not of the changing of any of you. \\ Ever yourself, you are always about \\ to be yourself in something else ever with me.
}

(The When Time 1-13)

It is noticeable that the poet uses the second person perspective which involves the reader in the actions of the poem. As if the reader is the central character of the poem. This gives a dramatic effect and at the same time turns the reader from being an object to be a major subject. The direct style of the poem is magnificent as it makes you feel that the poet is speaking straightforward to you. Carter insists that relief comes with being yourself. Sometimes you feel puzzled by all the constants around you. Then you feel that you are in a journey stopped by obstacles in your way. The word /stone/ indicates how these obstacles are rigid and cruel. In other words, these obstacles are the corrupted image made by colonialism to distort the oppressed identity. As a result, your identity becomes shattered under all these pressures. The metaphor in / you turn back questioning the tree/ clarifies how the hero is perplexed and needs to restore his identity again. Also, this image is a depiction of the persons' attempts to find a proper place in the new world. The person who sacrifices for his mother country is now asking it, seeking for a true sense of identity and refusing any imposed self-conceptions. The last lines declare the poet's principle as he will not give 
up his native identity, nor what he believes in. He says, /Ever yourself, to be yourself in something else ever with me/. He is not afraid of people disagreement with his views and considers their situation as their loss, not his.

National identity is closely linked to the resistance process, in order to gather the oppressed under one flag there should be a collective sense around one issue which is their nation. Frantz Fanon in his essay "On National Culture" explains that "national identity" reflects the combined revolutionary efforts of an oppressed people aiming at collective liberation; He says "A national culture is not folklore, nor an abstract populism that believes it can discover a people's true nature. A national culture is the whole body of efforts made by a people in the sphere of thought to describe, justify and praise the action through which those people has created itself and keeps itself in existence" (233).

In this sense, we find Carter's essay "The Lesson of August”,talking about people in India and their magnificent' welcome to the leaders of Guyana, stating, "And in turn, they expect from us internal unity, internal brotherhood based on the knowledge that whether our ancestors came from Africa or from India, we are one community in this land" (194). August represents the emancipation month in which the Guanines and the Indians made the great leap forward on the road of the national independence. This ongoing links between Fanon and Carter's beliefs about national identity demonstrate its significance as an essential element in the anti-colonial struggle.

Discussing the national identity as another aspect of identity, Carter has a deep faith that people at this point have to give up their personal identity and merge with the native one. No place for discrimination or any personal projects. The poet declares that they share common a destiny and their national identity is their umbrella that protects them from the enemy of separation. Keeping it powerful and solid is not an optional choice, it is a must. Carter ends his essay by saying, “...the unity we have created among us and the strength we sustain within us must always remain about us 
as we march against the crumbling ramparts of oppression, calumny, and gloom. This is the lesson of August" (ibid 195).

The complex character who suffers from a colonial experience is explored in Edward Said's book Culture and Imperialism as he claims that not only were the colonized constructed as different and other by the dominant regimes, but also, these regimes had the power to make the colonized see and experience themselves as "Other". Every dominant regime is formed by the fatal couplet, power and knowledge. But this kind of knowledge is internal, not external. It is one thing to position a subject or set of peoples as the Other of a dominant discourse. It is quite another thing to subject them to that "knowledge", not only as a matter of imposed will and domination, by the power of inner compulsion and subjective conformation to the norm (qtd.in Hall 225-226). Indeed, the exploitative history of the slave trade and colonialism has effectively stolen the identity of the oppressed people of the Caribbean and made them 'Other'. The traditions handed down from generation to generation have been radically changed. The poem "It Is for This That I Am Furious" clarifies Carter's point of view about this idea. He writes:

We all came naked here naked as the new born the new born in the light of day. we all came naked here and yet easy is it for me to be like wood like ant or roach in any dusty creviceempire of some loathsome spider's web it is for this that I am furious, my brothers if I am not furious my brothers I will be nothing more than a cow and I will die like a cow if I am not furious like a cow with a nose ring after years in the byre.

(The Hill of Fire Glows Red 1-3/ 9-19) 
Carter faces the reader with the obvious fact of our existence in this universe. We brought nothing with us to this world. He declares that it is easy to be like /wood, ant or roach/; it is easy to be any creature even if it was a solid body or an odious insect. But the fact is man is created as a human being with the honor of having the ability of choice. This is the reason why he is furious, he belongs to the humanity world, not to that /loathsome spider's web/ where there is no place for the weak, where there is discrimination between males and females and where there is a humiliation from other stronger creatures. The poet depicts an image which resembles what really happens in reality from the colonizers. Colonialism deliberately makes distinctions between people in order to ensure its control over colonized.

The poet is angry and calling his brothers to share him his anger. He can't figure out why there is injustice in the world even if we are all humans. He is eager to this unity with his brothers as he calls them more than once. If he is not angry, he will live and die like a /cow/. The simile in /a cow with a nose ring/ reflects his terror of being a hopeless creature with no right of choice. He is furious because he is defending his identity and his existence and needs his brothers to give him a hand to save their identity too. This is an acceptable point of view because if you want to create a national identity you need first to confirm your presence as a human being.

\section{The Search for Identity in selected poems by Mahmoud Darwish}

Identity cannot be detached from its historical and cultural context. It is linked with the colonized everyday resistant experience against the dominant powers. Thus, when colonialism attempts to distort the history of the colonized, the collective identity comes as a counter attempt and as a tool of the ideological resistance that preserves this history. It is the time for men of literature to be the freedom fighters who reflect this collective identity in their works. Referring to the Palestinian history, we have to mention that the most devastating blow to the Arabs came in 1948 with the establishment of the state of Israel and the transformation of the Palestinians into stateless people. The colonized Arabs struggled to gain their independence against 
the violent resistance of the colonizers. In "Resisting Colonialism through Nature", Hamoud Yahya and Ruzy Suliza classify this resistance into two forms. The first was armed resistance represented in three wars that took place in 1948, 1967 and 1973 between the Arabs and the Israelis over the Arab occupied lands. Until today, the Palestinians continue their armed and civil resistance against their colonizers, fighting for their right to establish their own independent country. The second is resistance through literature, particularly through poetry, that was inspired by these historical events. Since ancient times, an Arab poet was the voice of his nation and the tongue of his people. The ideal Arab poet has always been embodied in the image of the warrior poet who fights against injustice and oppression. In a similar fashion, Darwish assumes this kind of role played by Arab poets since ever (90).

Talking about the Palestinian identity and the role that the Palestinian poet Mahmoud Darwish played in preserving it, Erica Mena in her article "The Geography of Poetry" claims that the dual project of Darwish's work is simultaneously anticolonial, concerned politically with the establishment of an independent and selfdetermined Palestine free from imperial occupation. His poetry has become the voice of Palestine to the extent that he combines the private voice with the public; his personal experience reflects the collective experience of the Palestinian people. His work contains a universality born from specific suffering that reaches across the boundaries of language and nation to inscribe the national within the universal (111). Exploring the same idea, Salma Jayyusi in her essay "Mahmoud Darwish's Mission and Place", argues:

Mahmoud Darwish is the poet of Palestine identity par excellence. I am speaking here both of the personal identity of the poet and the collective identity of all Palestinians. The personal identity is rooted in the collective one, the latter being reinforced by the common plight and the common struggle people share ...the Palestinian might suffer and die alone, but his personal tragedy is linked to the tragedy of the whole people. . .this collective identity forms an integral part of the national narrative, and plays a major part in the ongoing resistance in its countless aspects, it represents a unifying factor, one that speaks 
of a similarity of experience, of a common memory that warms the heart. (viii)

In "Catastrophe, Memory, and Identity", Ahmad H. Sa'di argues that similar to various Third World peoples who have experienced centuries of colonization, the question of identity among Palestinians has become intimately connected to the restoration of the individual' subjectivity. Palestinians have to resort to reconstructing their identity because of dispersed and lacking national institutions that can play this role... Al-Nakbah is a Palestinian event related to the Palestinian collective identity as it connects all Palestinians to a specific point in time that has become for them an "eternal present". In order to give the Palestinians a hope in the independent future, major efforts should be made to reconstruct and preserve the past. Mahmoud Darwish's poetry uses identity, myth, and history to form a collective Palestinian voice. By doing this, he resists the hegemonic structures of Israel and the West by using it as a method of resistance. Darwish's poems reveal multiple faces to Palestinian identity (176-177).

As mentioned in the suggested quotation, $\mathrm{Al} \mathrm{Nakbah}$ is a major incident in the Palestinian history. Its effect on the formation of the Palestinian identity is still ongoing until this day. For Darwish, the trauma of losing his home as a child and, therefore, growing up as a stranger in his own homeland was the most influential factor in his life and on his poetry. In "Passport", Darwish reflects a strong dissatisfaction with the way Palestinian's identity is always put into marginalization due to Israeli aggression. The title of the poem refers to a visa to navigate from one place to another, including a sense of alienation and loss. He strongly asserts that his identity can't be simply wiped out as it is embedded in his land, nature and people. As a sincere representative of Palestinian identity, Darwish enjoys that spirit of resistance that enables him through his poem to create a whole connected world between the people and the land. The meaning behind "Passport" is that everything that the poet knew about his home place changed by the hands of the Israeli occupation. As they tried to strip him of his identity, he insists that if no one will recognize him, all the people's hearts will be his identity. He states: 
They did not recognize me in the shadows That suck away my color in this Passport And to them my wound was an exhibit

For a tourist

Who loves to collect photographs

They did not recognize me,

Ah ... Don't leave

The palm of my hand without the sun

Because the trees recognize me

Don't leave me pale like the moon!

All the birds that followed my palm

To the door of the distant airport

All the wheat fields

All the prisons

All the white tombstones

All the barbed boundaries

All the waving handkerchiefs

All the eyes were with me,

But they dropped them from my passport

Stripped of my name and identity?

On soil I nourished with my own hands?

Today Job cried out

Filling the sky:

Don't make an example of me again!

Oh, gentlemen,

Prophets,

Don't ask the trees for their names

Don't ask the valleys who their mother is

From my forehead bursts the sward of light

And from my hand springs the water of the river

All the hearts of the people are my identity

So take away my passport!

(Memory of Forgetfulness1-30)

The poem was written from the first person point of view as it mirrors the poet's personal experience. It begins with a sense of resentment as his nationality is altered and a new identity is imposed upon him. Not only the occupation insists on denying his existence but also it mocks on his wounds by changing him into a mere photo in an exhibit for tourists. Yet, he strongly feels that these papers can never show 
the depth of attachment between him and his native land. What colonialism doesn't really recognize is that the historical, natural and cultural bond is innate as nobody can wipe it out by some papers. The repetition in saying/ Do not leave/ confirms the severity of the need of support in his journey to prove his being.

In the second stanza, the poet screams that all the elements of nature witness his identity because it is a part of his existence. The poet repeats the word /All the/ just to confirm that there are others who know that the poet belongs to this land. The repeated word /All/ gives a meaning of inclusiveness as it has been employed as evidence to prove the fact of the poet's origin. Rather, he finds reassurance in the natural elements since their identity becomes an inseparable part of the landscape just by originating there. The poet exactly feels the same kind of deep-rooted connection with his native land. The connection between the poet and his land provides him the strength to completely reject the passport that tries to set him apart from his native land.

In the last stanza, the poet's anger is reflected in these lines /Stripped of my name and identity? /On soil I nourished with my own hands /Today Job cried out/Filling the sky / Don't make an example of me again! / Here he rejects any kind of moral, grand narrative like religious verses that encourage people to be patient. He feels that patience is not an option for Palestinians anymore. They have been obligated to be patient. By these images, the poet manages to express his suffering and outrage from being patient for too long. The allusion embodied in the symbolic Job, who waited patiently on the disease until God sent its mercy upon him, reflects Darwish's tiredness from the status quo. Maybe the poet doesn't have the patience of Job but he is obliged to it, despite torture, displacement, and alienation. In other words, patience for the poet is not a choice, it is an obligatory matter. Darwish views human beings just as another element of nature. He feels that human beings belong to the land exactly as a mountain or a river is rooted in the same land. As long as these nature elements never change its identity, also, the Palestinians will never quit

In short, this poem illustrates the bond between Darwish and the landscape of his country by highlighting the elements of nature and its relation to the theme of identity. As Zalina Azim et al. in an article entitled "Identity and Land in Mahmoud 
Darwish's Selected Poems"; state that these lines show that the trees and valleys know their own origin, just as the speaker himself is firm of his own identity and his homeland. The images of /From my forehead bursts the sward of light/ And from my hand springs the water of the river/ implicitly evoke the sense of interconnected resistance. Indeed, it seems that Darwish overtly and covertly wants to emphasize, on one hand, the colonizers could occupy his land, but they cannot erase his identity that is firmly attached to the occupied land. On the other hand, he aims at evoking the depth of the relation between Palestinians and their occupied land. Furthermore, $\mathrm{He}$ sows the seeds of the elements of nature and human identity to bud as tools of resistance. It is the embodiment of both Palestinian land as represented by "the trees", "the valleys", "light" and "the river's water" and the Palestinian identity symbolized by "all the hearts of people". Indeed, the elements of Palestinian identity and the aspects of the occupied land are skillfully merged in his poetry and it is difficult to say which of the two predominates (12).

In a culture of occupation and resistance, the history and the image of the oppressed are always in conflict with the image and history imposed by the oppressors. John Halaka in his article "Outsiders on the Inside" elucidates the previous notion saying that the entity that holds the regions of power has the upper hand in defining and shaping the public discourse in the struggle. This can be achieved by constructing and promoting a distorted image of the subjugated people in order to undermine their identity. The projection of a subverted identity by the occupier on the occupied raises confusing questions such as, who are we? Where do we come from? And where are we going? In the Palestinian / Israeli conflict, the construction and repression of identity continue to play a crucial role in how the parties view each other, how they view themselves and how the conflict is viewed, understood and treated in the international arena (84-85).

Consequently, as the colonial power in Palestine has the superiority, exile becomes like a permanent situation imposed by this power over the indigenous people of the land. Edward Said in his book The Question of Palestine argues the Palestinian identity asserting that each Palestinian community must struggle to maintain its identity on at least two levels: first, as Palestinians with regard to the historical 
encounter with Zionism and the loss of homeland; second, as Palestinians in the setting of everyday life responding to the pressure in exile (121).

Exile is a major element in the Palestinian identity formation. Exile has been enforced on the Palestinians' life and the return becomes a far reached dream to them. The theme that recurs in most of Darwish's poetry is the question of identity referring to the state of the Palestinians who have been forced into exile. As a result, his sense of his lost identity in exile runs deep into the words of his poetry. Palestinians feel another kind of exile. In his poem, "Who Am I, Without Exile?" The poet releases the unsettled identity, suffering and loss whether in a host country or in his home after a very long journey of deprivation. It is the struggle that is mingled with the yearning to the national identity. He is able to transmit his love for the land effortlessly and effectively in spite of the harsh Palestinian experience in exile. Darwish writes:

A stranger on the riverbank, like the river ... water binds me to your name. Nothing brings me back from my faraway to my palm tree: not peace and not war....

Nothing carries me or makes me carry an idea: not longing and not promise. What will I do? What will I do without exile, and a long night that stares at the water?

Water

binds me

to your name ...

Nothing takes me from the butterflies of my dreams

to my reality: not dust and not fire. ...

Our weight has become light like our houses in the faraway winds. We have become two friends of the strange creatures in the clouds ... and we are now loosened from the gravity of identity's land. What will we do ... what will we do without exile, and a long night that stares at the water?

Water

binds me

to your name ...

There's nothing left of me but you, and nothing left of you but me, the stranger massaging his stranger's thigh: $\mathrm{O}$ stranger!... 
And what will we do?

What

will we do

without

exile?

(The Bed of the Stranger)

Exile becomes for the Palestinians a permanent condition in which they attempt to express the wounds of a lost identity. They are a people who were transformed from being a nation with a great civilization into a mere nation of refugees. From the first lines, the poet states this fact by describing himself as a stranger sticking to the riverbanks. The river is a symbol of life as water is the hope that preserves it. By sticking to the river, the poet means that he will defend his existence and identity as long as this river contains water. The poet reveals his despair as he is still suffering exile, dislocation, and loss. Nothing can bring him back to his home, neither war nor peace; just memories of his landscape. He believes that there is no benefit from all peace talks that could not achieve a definite peace that can guarantee the Palestinians' rights of return to their home. In spite of his continuous yearning to his people and home, he admits that exile becomes his obligatory world. The poet recognizes well that his identity is reconstructed in exile.

The repetition in the image /water binds me to your name/, emphasizes the poet's desire to be involved in the water that brings life to his soul and revives his heart. The image sheds the light on the reality of the situation in Palestine. This poem reflects the Palestinians struggle in exile and the suffering of the scattered identity, whether in occupied land or outside. The poet explains how much he got accustomed to his imagined world in exile as he refuses to face the reality with its harshness and cruelty. The realities of the new location, political, social, and cultural conditions imposed an obligatory reshaping on the lives of the Palestinians. For Darwish, the exile and the reconstruction of identity are well expressed as an accomplished fact. The monotony in /our weight has become light like our houses in the faraway winds/ clarifies his sorrow for being very unworthy exactly like his house. The pain of being marginalized exceeds its limit as he becomes very light thrown by the wind anywhere. Also, the metaphor in /strange creatures in the clouds/ makes the visual imagery of 
the poet and his home very vivid by describing them as two strange birds met in the sky. All these images illustrate the strong bond between Palestinians, as strangers, and their imagined community, with its new form after many years of exile. The poem, in general, reveals the internal and the external echo of inescapable exile, at the two levels the psychological and the physical one.

The rhetorical question / what will we do without exile? / which has been repeated throughout the whole poem implies a deep sense of bitterness and agony. This indicates the crucial role of exile in the reshaping of the Palestinian's identity. That is the reason why the poet clings into the elements of his home' landscape as a sign of inspiration to stick more and more to his identity. The image of river, water and palm tree, explores that sense of landscape and its symbolic representation of the struggle of the indigenous people inside and outside Palestine. It shows the instability of life in exile under the influence of dislocation which requires moving from one place to another. On an artistic perspective, the image of the landscape is introduced as a symbol of survival. Also, the image of the stranger who has nothing but his country and the country which has nothing but the stranger expresses the poet's nostalgia mixed with an irony from this condition. Life in exile which is imposed on the Palestinians resulted in an emotional turmoil, feelings of humiliation and indignity but at the same time, Palestinians have no choice but to accept it as it is. Darwish shows that Palestinians want to create a new life in exile that is full of short moments of pleasures while they expect the worst at any moment in their exile. They are troubled by the consequences of exile and the painful sense of the shattered identity from their motherland.

The use of myth in the battle of occupation is widely noticeable when we deal with the theme of identity. This is what colonialism makes in order to justify its hegemony over the occupied lands. Thus, creating fake myths to legitimize its deeds will help in raising the colonizer's image and despising the colonized one. By doing this, the major goal of colonialism to distort the self-identity of the colonized will be achieved. This weapon of importing powerful myths is employed by The Israeli occupation to give itself the historical seniority in occupying Palestine. These myths become the excuse for the colonial powers to subjugate the oppressed. Ipek Celik in 
his essay "Alternative History, Expanding Identity" claims that for the postcolonial authors, as for many others, "dusting off the myth" means to raise their controversial voices against the image in the colonial history of a fixed, eternal, "Clean" past. This past still perpetuates colonial identities and divisions, therefore, it has to be rewritten by the colonized and oppressed (283).

In this regard, rewriting myths will be in the center of the anti-colonial poets' vision in order to destroy the homogeny of the colonizers over the colonized. Also, in order to reveal the falseness of these politicized myths. Thus, the Palestinian identity has had to assert itself in spite of the appropriation and hegemony of the land. Balraj Dhillon in his essay "Subaltern Voices and Perspectives" states that Darwish employs myth to resist Zionist appropriation of it, and does it from the perspective of the oppressed as he writes from a sense of community in envisioning the past. The poet's employment of myth is providing an alternative image of these myths that were thought to be rigid and definitive. One of Darwish's poems which employs myth is "Phases of Anat." He states:

I want you both, together, love and war. Oh Anat to hell with me .... I love you, Anat! ... We broke like a fence over your absence ... Our prayers calcified. Nothing lives after your death ... Perhaps new goddesses will descend upon us in your absence and we'll be ruled by a mirage ... You'll return. You'll return the land of truth and allegory, the land of Canaan-the beginning/

(The Adam of Two Edens)

In order to fully understand the poem, a background of the goddess "Anat" must be observed. It is the moon goddess, distinguished herself in the Canaanite epics with strength and courage; and though she became known as a warrior she was also identified with fertility and considered to be the goddess of life. Her personality is one full of dichotomies; she is the goddess of life and death, fertility, and war, mother, 
and warrior. Darwish mourns her loss and calls for the return of the goddess whose influence spreads over Canaan, Syria, and Phoenicia. Anat is a controversial figure, a figure that is elusive in the sense that she is open to a variety of interpretations and is not restrained by one tradition but shared among many different cultures (52).

Munir Akash in the introduction of The Adam of Two Edens says that through this story readers are transported to another lost Palestinian realm. "In the ancient Palestinian pantheon, Anat is responsible for the growth of plants, animals, and fertility in humans. It is she who brings forth the desire that generates the primal energy of the universe and bestows fertility onto all things" (35), Darwish's choice of Anat is no coincidence as there are many places in Israel are named after her, yet the poet remembers Anat in a very particular way, employing the ability to interpret her in his own way.

The colonialists make use of the past to gain privileges over the oppressed people. They fabricate history and politicize myths in order to justify their domination. Darwish in this poem tries to introduce an alternative history to resist against the fabricated one made by the colonizers. The poet attempts to deconstruct the past that has been exploited by the colonizers and used to perpetuate their colonial hegemony. Balraj Dhillon in his essay "Subaltern Voices and Perspectives" explains that Darwish is not simply deconstructing the old myth of Anat, but by challenging the very appropriation of Anat by Zionist discourse, he is providing an alternative myth from a subaltern perspective. The poet is directly challenging these structures, using myth as a medium. He doesn't create a new myth, but he does rework an existing one, and

gives a new version, an alternative to the appropriation of the existing myth. "The Phases of Anat" speak to this sense of community and its vision of the past, enabling Darwish to employ myth as an effective tool to resist appropriation of Zionist dominance (53-54).

\section{Conclusion}

After we review the concept of identity in both Carter and Darwish' selected poems, one can conclude that both agree that preserving identity is an essential 
component in the resistance struggle that cannot be ignored or undervalued. Although both of them belong to two different intellectual worlds, but it is clear that resistance is a universal language that imposes itself anywhere. Both have a profound belief in the power of poetry as a weapon of survival. They use it to counter the colonial hegemony over their lands.

From the first glance when the reader navigates the resistance poetry for both, one finds that the image of the ancestors is constantly present. The close link between the concept of identity and going back to the past is a predominant theme in their works. This is repeated throughout their poetry, whether by using explicit references or by using symbols. This comes from the poets' deep understanding towards the colonial ideology that seeks to destroy the colonized landmarks and bring another alternative culture that serves their colonial goals. This destruction includes not only erasing the cultural legacy of the occupied country but also includes the destruction of the individual's identity and minimizing his self-image. They preserve the heritage of ancestors from loss by commemorating it in their poetry.

Carter's view to the history of the ancestors differs from Darwish as the former is trying to gather his people around one collective identity based on a common legacy of slavery and colonialism, while the latter does not need to introduce his ancestors this way. Darwish's historical roots are deeper than Carter with its significant evidence mentioned in the holy books. For the Palestinians, the conflict lies around refuting the Jewish claims about owning the land. The censorship that the Israeli occupation imposed on the Palestinians aims at demolishing their identity. As a result, Resistance literature originally comes to light as an attempt to break this censorship or what Kanafani called the "cultural siege".

Like many poets across the world writing in the teeth of cultural and political oppression, Carter and Darwish have been subjected to troubles by the colonial authorities many times. They were imprisoned and sometimes as in Darwish's case exiled as a punishment for their anti-colonial thread. These experiences had a significant impact on their poetical works. The imperialists know quite well the 
influence of the artists on people that is why their works were banned. For Carter, the imprisonment experience has a deep effect on his poetical journey as it increases the sense of defiance and steadfastness which conveyed to his oppressed people. Moreover, this cruel experience helps in spreading his poetry among people. At the time when colonialism was keen on preventing his poems, people memorized and turned it into songs of resistance. Carter's influence as a resistance poet is widely acknowledged in the Caribbean for being the voice of the oppressed. He has never left Guyana and maybe this is the reason why he didn't get a great fame outside the Caribbean. Carter had not been exposed to the experience of exile and that differs completely from Darwish who spent most of his life being exiled moving from one country to another. This sort of stability affects Carter handling to the theme of identity in his poetry which appears clearly in the use of language, imagery, and attitude.

Eventually, the exile is intimately connected to the poetics of Darwish. He has experienced it since his childhood, thus, it plays a major role in the formation of the personal identity of the poet himself. Not surprisingly that his poetry is preoccupied with the theme of exile. It is not an individual case as exile is the painful fate of all the Palestinians. Thus, Darwish's tragedy in exile reflects the suffering of his entire nation. This also resulted in a deep sense of nostalgia as the return becomes like a dream for the Palestinians. Consequently, the image of the homeland in Darwish's poetry is always embodied in an image of a mother or a lover who will embrace her absent son returning from exile. Darwish lived in exile more than twentysix years of his life moving between countries. Although he returned to the land of Palestine, but he has suffered from house arrest and was forbidden from entering certain places in Palestine. This leads us to another meaning of exile as it does not mean being just expelled from your homeland but it can also mean being deprived of your land when you are living in it. Darwish suffers from two kinds of exile the external and the internal one. Therefore, he had to fight on two fronts, abroad in order to provide a correct image of Arab Palestinian identity instead of the nigative image of the Palestinians as terrorists. On the inside level, it was like a fight for the 
preservation of his national identity from the deliberate distortion made by the Israeli occupation policy.

Elizabeth M. Deloughrey et al in their book Caribbean Literature and the Environment state that "myth became the origin narrative for the entire region and as it continues to struggle with it because of its capacity to articulate imperial, colonial, and postcolonial discourses of power" (87). In spite of the significant role myth plays in the formation of the national identity, we find Carter does not rely much on this technique of deconstructing myth in forging the Guyanese identity. Only two or three poems in his poetic works which deal with mythology, thus we cannot affirm that it is a prominent technique used by Carter.

On the contrary, we find a long phase of Darwish's poetry engages with the notion of deconstructing the myth as a tool of resistance. Israeli occupation invented the myth of the Promised Land as an excuse for raping the land of Palestine. Through such myth-making, Israelis managed to root new Jewish generations in Palestine within a few years. Thus, myth becomes an effective tool in the colonial battle. Darwish recognizes well the seriousness of this tool by employing his poetry as an arena of struggle to fight the Jewish illusions. As Ipek Celik in his essay "Alternative History, Expanding Identity" argued that "Darwish's poetry delves into the politics of narrating history and sustaining myths, in order to reveal the complexities and contingencies history writing and mythmaking bear of formulating Palestinian national identity" (273). Through his poetry, Darwish reflects the integration of history and mythology as a device of power and domination and as a method of shaping the Palestinian identity.

It is noteworthy that Darwish uses the elements of nature in his writings as symbols for the Palestinian resistance. This is clear in his adoption of the Palestinian landscapes such as trees, mountains, sea, and rocks. The poet himself says "My poems do not deliver mere images and metaphors but deliver landscapes, villages, and fields and deliver place" (qtd.in Cliek 275). He derives strength from these natural symbols 
to assert his shattered identity. In other words, he employs the landscapes to prove that his identity is as solid as its existence.

Unlike Carter who already uses the landscape in his poems but not in an interactive way like Darwish does. This is strongly suggested by many critics like Edward Brathwaite in his article "Resistance Poems" claiming that "Carter himself has little of landscape, at least in the physical sense of local color, in his poems" (130). This agrees with Eusi Kwayana's opinion about Carter's little use of the landscape, as he states in his essay "The Politics of The Heart" that "Carter in his poetry does not make photographs of nature. His love of the Guyanese landscape is deeply rooted yet they just form a natural backdrop in his poems" (176).

\section{$\underline{\text { Work Cited }}$}

Akash, E. M., and Daniel Moore. The Adam of Two Edens. New York: Syracuse University Press, 2000. 35. Print.

Brathwaite, Kamau. "Resistance Poems: The Voice of Martin Carter." All are Involved; The Art of Martin Carter. Ed. Stewart Brown. England: Reepal Tress Press, 2000. 130. Print.

Carter, Martin. "The Lesson of August." University of Hunger. Ed. Gemma

Robinson. Northumberland: Bloodaxe Books, 2006. 194,195. Print.Celik, Ipek." Alternative History, Expanding Identity: Myths Reconsidered in Mahmoud Darwish's Poetry." Mahmoud Darwish, exile's poet: critical essays. Ed. Khamiss, Hala, Khamis Nassar and Najat Rahman.

Massachusetts: Mass Oliver Branch Press, 2008. 273, 275, 283. Print.

DeLoughrey, Elizabeth M., Renée K. Gosson, and George B. Handley. Caribbean Literature and the Environment: Between Nature and Culture. University of Virginia Press, 2005. 87. Print. 
Dhillon, Balraj. "Subaltern Voices and Perspectives: The Poetry of Mahmoud Darwish." Centre for Studies in Religion and Society 9.1 (2010): 52-54. Print. Fanon, Frantz. "On National Culture." Trans. Richard Philcox. The Wretched of the Earth. New York: Grove, 1963. 233. Print.

Halaka, John. "Outsiders on the Inside" Nebula 5.3 (September 2008): 83-85. Print.

Hall, Stuart, and Gay P. Du. Questions of Cultural Identity. London: Sage, 1996. 597598. Print.

Jayyusi, Salma. "Mahmoud Darwish's mission and place in Arab literary history." Mahmoud Darwish, exile's poet: critical essays. Ed. Khamiss, Hala, Khamis Nassar and Najat Rahman. Massachusetts: Mass Oliver Branch Press, 2008. viii. Print.

Kwayana, Eusi. "The Politics of the Heart." All are Involved; The Art of Martin Carter. Ed. Stewart Brown. England: Reepal Tress Press, 2000.176. Print.

Laughlin, Nicholas. "What 'Caribbean' Can Mean." Arts Journal: Critical Perspectives on Contemporary Literature 2.2 (2006): 87. Print.

Lazim, Zalina M, Hamoud Yahya Ahmed, Ruzy Suliza Hashim, and Ravichandran Vengadasamy. "Identity and Land in Mahmoud Darwish's Selected Poems: An Ecopostcolonial Reading." International Journal of Applied Linguistics \& English Literature 1.6 (2012): 12. Print.

Mena, Erica. "The Geography of Poetry: Mahmoud Darwish and Postcolonial Identity." Human Architecture: Journal of The sociology of Self Knowledge 2.s (2009): 111. Print.

Premdas, R. Ralph. "Ethnicity and Identity in the Caribbean: Decentering a Myth." The Helen Kellogg Institute for International Studies. Working Paper \#234 December (1996): 10. Print. 
Rohlehr, Gordon. "Man's Spiritual Search in the Caribbean Through Literature.", Troubling of the Waters, A collection of papers and responses presented at two conferences. Ed. Idris Hamid. San Fernando, Trinidad: Rahaman. 1973. 187. Print.

Sadi, Ahmad H. "Catastrophe, Memory and Identity: Al-Nakbah as a Component of Palestinian Identity". Israeli Studies 7.2 (2002) 176-177. Print.

Said, Edward. The Question of Palestine. New York: Vintage Books. A Division of Random House. 1980. 121. Print.

---. Culture and Imperialism. New York: First Vintage Books, 1994. 209- 213. Print.

Seecharan, Clem. "The Shape of The passion: The Historical Context of Martin Carter's Poetry of Protest (1951-1964)." All are Involved; The Art of Martin Carter. Ed. Stewart Brown. England: Reepal Tress Press, 2000. 31. Print.

Yahya, Hamoud and Ruzy Suliza Hashim. "Resisting Colonialism through Nature: An Ecopostcolonial Reading of Mahmoud Darwish's Selected Poems." Holy Land Studies 13.1 (2014): 90. Print. 